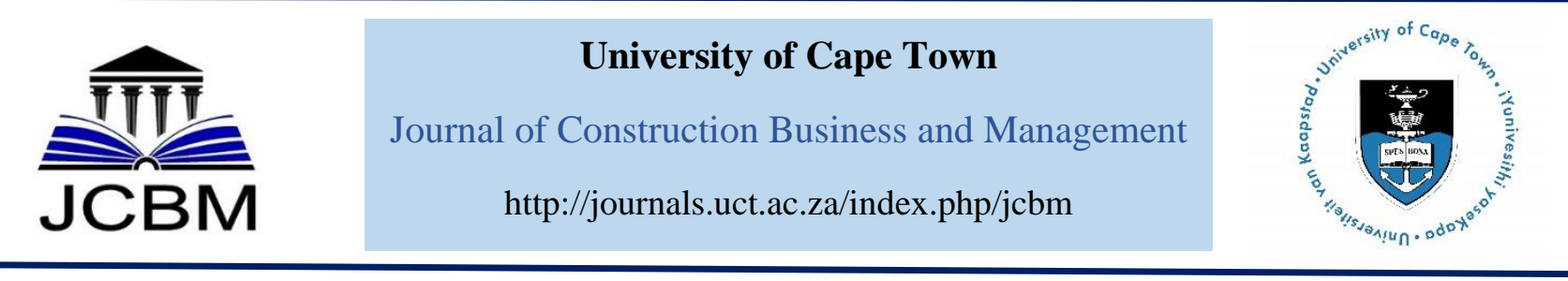

\title{
Barriers to the Effective Regulation of the Building Construction Industry: An Empirical Analysis
}

\author{
W. O. Omollo ${ }^{1}$ \\ ${ }^{1}$ Department of Planning and Development, Kisii University, Kenya
}

Received 29 April 2019; received in revised form 27 May 2019, 2 July 2019; accepted 17 July 2019 https://doi.org/10.15641/jcbm.3.2.745

\begin{abstract}
This study investigates key barriers to the effective regulation of the building construction industry in Kenya, a case study of Kisii Town. It was guided by the Public Interest Theory of Regulation, which provided the underpinning elucidating why the building construction industry in Kenya needs regulation. The target population comprised 84 registered building contractors with a sample size of 66 selected using simple random sampling by application of random number table. As regards limitation, the study does not measure the extent of quality assurance within the construction industry, but rather delve on the key factors impeding its effective regulation. The research findings show that ineffective regulation of the construction industry in Kisii Town was prompted by the joint activities of building development contractors and limitations of the National Construction Authority (NCA) (the regulator). Regarding the activities of building contractors, identified barriers included failure to refer to key legislation that regulates the construction industry, failure to obtain statutory approvals of building development, and laxity to invite supervision of ongoing projects by planning authorities. Conversely, factors elucidating why NCA was not successfully regulating the construction industry included inadequate multi-sectoral coordination, inadequate surveillance, and limited sensitization of key stakeholders. Drawing from these findings, the study recommends regular monitoring and enhanced enforcement that would promote compliance and sensitization of contractors with applicable standards and regular inspections of ongoing projects. Also, establishing a coordinating committee to harmonize institutions that deal with development control.
\end{abstract}

Keywords: Construction Industry, Kenya, Kisii Town, Regulation

\section{Introduction}

The global construction industry was in 2017 , valued at US\$ 10.4 trillion and projected to annually expand by $3.7 \%$ to the US $\$ 12.4$ trillion by 2022 (Amiri and Bausman, 2018). The construction sector is widely acknowledged as among the top accelerators of prosperity owing to its role in the economic uplift through employment generation. The industry, in the same way, plays a vital role by being a leading source of income within the formal and informal sectors (Khan, 2008). By its nature, the construction industry has the prospective for mobilizing and efficiently exploiting human capital and physical resources towards the development and improvement of housing along with the attendant infrastructure to enhance economic efficiency (Oladrin et al., 2012). This makes it among the noticeable

\footnotetext{
${ }^{1}$ Corresponding Author.

Email address: wochieng@kisiiuniversity.ac.ke
}

contributors to economic prosperity since its products provide indispensable public and private infrastructure that supports undertakings such as trade, amenities and services. As such, it remains significant on account of its end product, effectively making it a requisite for economic transformation (Wibowo, 2009).

However, notwithstanding its acclaimed significance, inadequate regulation of the industry may attract salient challenges which could potentially negate the much anticipated economic benefits. To cite an example (Gichana and Nyagesiba, 2016), on $11^{\text {th }}$ October 2017, six people were left dead with several injured after a threestory building that was under construction in Kisii Town collapsed, a problem credited to poor workmanship and the disregard of building regulations by developers and their contractors. Unregulated developments in Kisii Town have also led to noncompliance with standards such 
as building coverage ratio and floor area ratio, leading to unsustainable development (Omollo et al., 2018). No country can, therefore, prosper if its construction industry is not well-regulated (Gacheru and Diang'a, 2015).

Regulation of the industry is, therefore, obligatory given that contractors and their clients are responsible for the development of structures occupied by millions of people. In this esteem, the construction industry in Kenya and by extension in Kisii Town is hence not an exception. The objective of this study was, therefore, to examine key barriers to the effective regulation of the building construction industry in Kenya using Kisii Town as a case study. In terms of rationale, the study provides policy formulating bodies in developing and developed countries with pragmatic options towards the effective regularization of their residential building construction industries, a strategy for attaining sustainable urban development. Furthermore, the study makes a methodological contribution to the literature on building development control by empirically elucidating the correlation of factors limiting the regulation of the construction industry using Exploratory Factor Analysis (EFA) and Confirmatory Factor Analysis (CFA).

\section{Barriers to the Regulation of Construction Industry: A Literature Review}

Compliance with building regulations and laws is a legislative requisite in the construction industry (Windapo and Cattel, 2010). Notwithstanding this obligation, a growing body of literature suggests that the industry's regulation continues to emerge as one of the key challenges of achieving sustainable development.

A study of Mozambique's construction industry by Nhabinde et al. (2012) established that inadequate regulation was prompted by contractors who were not certified, insufficient policy and institutional coordination, and a lack of qualified personnel. These findings relate to that of Windapo and Cattel (2010) who argued that the South African construction industry had a skill and knowledge gap along with the fact that most supervisory positions were held by people who, although not well educated, were more experienced. As such, the extent of non-compliance with stipulated regulations was high amongst the unqualified and less experienced firms not registered with the country's Construction Industry Development Board. Further, some site managers were unaware of the legislation that regulate building construction industry. Regulation of the building construction industry may also be affected by noncompliance with approval conditions. For instance, Ngetich et al. (2014) found out that $38 \%$ of the applicants who obtained a development permit between 2005 and 2010 in Eldoret Town, Kenya, failed to comply with stipulated building regulations.

Above findings compares with that of by Hedidor and Bondinuba (2017) who averred that the informal construction sector in Ghana paid little attention to the approved regulations for the construction of buildings. This was elicited by low levels of training and competence of artisans within the industry. On account of inadequate regulation, low-quality training duped apprentices into thinking that they were fully qualified when they were not. In Mombasa, Kenya, Gacheru (2015) found out that barriers to the regulation of construction industry included the inadequate capacity by NCA to detect errant contractors through frequent surveys, weak enforcement of regulations, inadequate sensitization and poor attitude of contractors towards the regulatory bodies.

According to Ofori-Kuragu (2016), key challenges to effective regulation of the construction industry in Ghana included lack of coordination and a clear agenda to address the apparent problems that afflict performance within the industry. As additionally corroborated by Hedidor and Bondinuba (2017), the country lacked a multi-stakeholder representative body that could provide leadership in the pursuit of reforms in the Ghanaian construction industry. In their research, Callistus et al (2014) through a case study of small- scale contractors in Ghana demonstrated that some of the barriers to effective regulation of the industry were corruption, lack of coordination between designers and contractors, inadequate monitoring and feedback by relevant authorities, and lack of training on quality for staff.

In an attempt to further investigate compliance and enforcement challenges concerning the national building regulations process in South Africa, Twum-Darko and Mazibuko (2015) established that developers had a low level of awareness and understanding of the regulatory role of implementation of National Building Regulations. Other challenges included ineffective communication channels between the stakeholders and the regulator and also inconsistencies of the enforcement of the legislation by various local authorities.

A further study by Kumar and Pushplata (2015) on compliance with building regulations for the hill towns of India demonstrated that the enforcement and surveillance mechanism to ensure compliance was not adequate. Given this, there were fewer initiatives by regulatory authorities in an attempt to stop illegal and unplanned developments. Moreover, there was a shortage of technical experts in hill towns who could implement existing building regulations in addition to ensuring that construction activities were carried out in compliance with the approved regulations. These findings are further corroborated by Adebowale et al. (2016), who established that a key challenge within Nigeria's construction industry included poor workmanship and inadequate supervision. In this case, supervision should constantly aim to ensure that building developments are undertaken as approved by planning by authorities.

From the preceding literature review, key barriers to effective regulation of the construction industry may be summarised to include insufficient coordination, lack of qualified staff within firms, inadequate capacity by regulatory authorities, inadequate enforcement and surveillance, and lack of stakeholders' sensitization. The current study, however, examines the statistical relationship between key barriers that influence effective regulation of the construction industry.

\section{Overview of the Construction Industry in Kenya}

Kenya's construction industry is well-developed and characterised by established businesses that primarily engage in housing projects, engineering services such as 
roads, and allied trade services (Competition Authority of Kenya 2017). Currently, the industry remains a significant multiplier in the country's economy through its remarkable impact on the country's Gross Domestic Product (GDP). In this way, it presents a key driver of economic prosperity. Kenya's construction industry respectively grew by $6.1 \%, 13.1 \%, 13.8 \%, 9.8 \%$ and $8.6 \%$ between 2013, 2014, 2015, 2016 and 2017 in that order, denoting a thriving sector. Noticeably, in 2015, the industry accounted for $7 \%$ of Kenya's GDP, further maintaining that the country has a well-developed construction industry (Kenya National Bureau of Statistics, 2018).

Kenya's economic outlook, in addition, suggests that the construction industry is ranked among the leading sectors that have continued to attract investors with a particular interest in areas such as transportation, upgrading of informal settlements and slums, the supply of construction materials, construction of housing, and manufacturing (Competition Authority of Kenya 2017). The construction industry in Kenya is regulated by the Government and its associated agencies through various legislations to ensure that this growth does not impact on the built environment.

The industry is regulated by the NCA, a state corporation established under section 3 of the NCA Act (2011). According to section 5 of the Act, the Authority has a mandate of regulating and building capacity within the construction industry. Further, it accredits site supervisors and skilled construction workers, in addition to monitoring the performance of all contractors. To attain this, the Authority has grouped construction companies depending on the contract cost they are permitted to handle together with the academic qualifications for the proprietors of the firms (the Republic of Kenya, 2011). The Act is operationalized through regulations that give NCA the mandate of regulating, promoting quality assurance and researching matters dealing with construction (the Republic of Kenya, 2014). A significant critique of the NCA Act is that it does not pay attention to the enforcement of planning standards during the inspection of construction projects. Moreover, the Act has not granted the NCA statutory powers of prosecuting errant contractors and developers.

Apart from NCA, building construction industry in Kenya is also regulated by county governments through development control following Section 36 of the Physical Planning Act of 1996 (The Republic of Kenya, 1996). This legislation, under Section 29, empowers the county governments with the mandate of developing bylaws which are essential in controlling zoning as concerns use and density of development, considering and approving all applications for development, prohibiting the use and development of land and buildings towards promoting orderly development and granting all permissions for development. Section 30 further prohibits any person from undertaking development within the area of a county government without a permit issued by the respective county government. A key limitation of the Physical Planning Act of 1996 is that it is too lenient when it comes to reprimanding developers who do not comply with the requirement of obtaining a development permit. For instance, section 30 (2) of the Act prescribes a penalty of only Kshs $130,000 \quad(1,284.40$ USD). This is low considering the impacts that may be brought by unregulated construction industry such as the collapse of buildings.

The requirements of the Physical Planning Act of 1996 are additionally augmented by the Building Code of 1968 where Section 16 (1) compels a person intending to develop a building in addition to first obtaining a development permit to also give the appropriate county government, a Notice of Inspection showing the date and time when the building construction, plumbing and drain laying will commence (the Republic of Kenya, 1968). Further, the following are required to be ready for inspection: foundation bed, foundation concrete, damp proof course, ceiling, concrete after shuttering is removed, concrete after shuttering is removed, drainage, plumbing installations, and sewer connection. In effect, the Code makes it obligatory for the inspection of buildings during the construction process in addition to issuing certificates of occupancy to ensure that completed buildings have complied with the stipulated quality assurance standards.

\section{Study Objective, Scope, and Theoretical Underpinning}

The objective of this study was to investigate the barriers towards effective regulation of the building construction industry in Kenya, a case study of Kisii Town. Although county governments in Kenya also regulate the construction industry, the scope of this study was, however, limited to NCA since it retains the exclusive mandate of registering and accrediting contractors in Kenya. Concerning theoretical orientation, it is anchored in the Public Interest Theory of Regulation (PITR). PITR postulates that unregulated economic markets have a predisposition of operating inadequately by focusing on the interests of individuals while overlooking the significance of society (Christensen, 2010). Hence, to monitor such markets, the state has to intercede through regulations.

As the leading statutory governing authority, the state consequently promotes the concern of the society at large instead of enacting laws that would favour it as an overarching regulator. In the context of the present study, the theory rightly supports why the construction industry in Kisii Town necessitated statutory regulation by NCA and other planning authorities to ensure compliance with set regulatory standards. This is because building development control is procedurally effected through compulsory directives dispensed and enforced by the agencies of the state. In this case, developers who do not comply consequently attract stiff penalties as may be specified in the applicable legislation.

\section{Research Methods}

\subsection{Background to the study area}

Kisii Town as the administrative capital of Kisii County lies about $120 \mathrm{~km}$ to the South of Kisumu city, the thirdlargest urban area in Kenya, and $320 \mathrm{~km}$ West of Nairobi city, Kenya's capital city. Spatially, the town covers an area of $34 \mathrm{~km} 2$. Kisii town has a topography that is typified by several valleys. While Nyanchwa Hills, which 
lies at an altitude of approximately $1800 \mathrm{~m}$ above sea level is located in the Southern part of the town, Mwamosioma Hills, which similarly rises to around $1800 \mathrm{~m}$ above sea level is located in the Northern part of the town. Further, rising to $1950 \mathrm{~m}$ above sea level to the Southern part of the town is Bobaracho and Gesarara hills. The town is well drained by several rivers which collectively form the River Riana tributaries. The population of the Kisii Town in 2017 was estimated at 90,100 and projected to 140,118 by 2032 (Omollo, 2018). This increase is likely to intensify land use development, therefore attracting more investments in the construction industry. However, if this transpires in the absence of an effective regulatory framework by designated statutory authorities, challenges such as non-compliance by stakeholders in the built environment are bound to increase at the disadvantage of sustainable land use planning.

\subsection{Target population, sample and sampling design}

The target population for the study comprises of 84 registered contractors whose scope of operations covered building development obtained from the NCA regional office in Kisii Town. A Sample Size Determination Table that Krejcie and Morgan (1970) recommends was after that used in selecting the desired sample size of 64 . Questionnaires with a thematic grouping of structured and unstructured questions were then administered to sampled registered building contractors after a pilot study.

\subsection{Validity and Reliability}

The study adopted content validity, defined by Kothari (2004) as the degree to which an instrument used in research offers sufficient coverage regarding the phenomenon under analysis. To comply with this requirement, two experts in building construction management were given the questionnaires. In this context, while one evaluated the concepts that the instruments were measuring, while the other considered if the items sufficiently embodied the notion under investigation. Research Instruments were in the end enriched based on the two expert opinions along with a pilot test that was successfully undertaken in Nyamira Town, $25 \mathrm{~km}$ from Kisii Town.

The current study adopted Cronbach Alpha in the testing of reliability. The test was developed by Lee Cronbach (1951) to offer a measure of internal consistency. According to Goforth (2015), in an attempt to provide a general computation of item consistency in a questionnaire, the reliability coefficient varieties from 0 to 1 . In this case, if the alpha $(\alpha)$ coefficient is higher, the questions are more likely to share covariance and possibly measure the same fundamental concept.

\subsection{Analysis of Data}

Both descriptive (cross-tabulation and percentages) and inferential (Exploratory Factor Analysis (EFA), Pearson's bivariate correlation coefficient, and Confirmatory Factor Analysis (CFA)) statistics were used in data analysis. While cross-tabulation and percentages were used in exploring the descriptive relationship between categorical variables, Pearson's Bivariate Correlation was used in testing the relationships among selected variables.
Regarding EFA, the multivariate technique was used in identifying latent constructs or components through Principal Component Analysis (PCA) and reducing observed variables into smaller sets to facilitate easier interpretations. It was applied to determine why NCA could not effectively regulate the building construction industry in Kisii Town. CFA was employed alongside PCA to validate the factor structure of observed variables. This allowed testing of the proposition that relationships between observed variables and their latent constructs existed.

\section{Results and Discussions}

\subsection{Survey response rate and reliability test}

The obtained response rate for questionnaires administered to contractors was $70 \%$. This was above the minimum of $50 \%$ recommended by Mugenda and Mugenda (2003). It was concluded that the responses were sufficiently representative for drawing logical deductions as well as in making key policy recommendations towards attaining an effective regulation of the building construction industry in Kisii Town. As suggested by Kothari (2004), the outcomes of pilot studies ought to be documented in research. After piloting, the questionnaire's reliability was tested using Cronbach's $\alpha$. Consequential Cronbach's $\alpha$ was 0.834, which demonstrated very high levels of internal consistency. Consequently, no variables were dropped for that reason.

Having examined the response rate and results of the reliability test, the next subsections now present the research findings on barriers to the regulation of the construction industry in Kisii Town. In this setting, barriers to regulation are discussed under two subsections: factors induced by registered building contractors who have a duty of ensuring compliance and those prompted by NCA as their regulator.

\subsection{Factors induced by building contractors}

According to Anyanwu (2013), a contractor is a crucial expert at the centre of any building construction. The contractor's primary duties entail coordination of all activities and taking charge to ensure that the project is developed as per the specifications in the approved building plans. The contractor must ensure that the construction process complies with all statutory requirements at the pre-construction stage, construction and close-out phase.

6.2.1 Laws that guide building contractors

It is the responsibility of contractors to ensure that they make reference to applicable laws in the process of building development. The study as such sought to find out which laws guided them before commencing construction, during construction and in postconstruction. Results showed that a majority (57.9\%) made reference to the NCA Act of 2012, followed by the Environmental Management and Coordination Act (EMCA) of 1999 (10.5\%), the Physical Planning Act (Cap. 286) and the Building Code (each 7\%) and the Ministry of Public Works regulations (5.3\%). Nevertheless, $10.5 \%$ were not aware of any such laws. 
Findings suggest that $12.3 \%$ never referred to any law, while only $7 \%$ referred to the Physical Planning Act (Cap. 286). It draws attention to why $27 \%$ of developers never obtained development permission, thus providing room for flouting building regulations. Such inconsistency in the application of legislation related to development is, therefore, among the key challenges undermining effective regulation of the construction industry in Kisii Town.

6.2.2.Approvals obtained by contractors and guiding planning standards

Building contractors in the study area also have an obligation of ensuring that they obtain the correct approvals from clients before commencing development statutory process. Key approvals as per various legislations include notification of approval by the Physical Planning Department (PPD) through Form PPA2, permission by the National Environment Management Authority (NEMA) through Environmental Impact Assessment (EIA) license, and project registration by NCA (Table 1).

Table 1: Types of approvals contractors obtained from clients

\begin{tabular}{lc}
\hline $\begin{array}{l}\text { Type of Approval Obtained from } \\
\text { Client }\end{array}$ & Per cent \\
\hline Approval by PPD & 10.7 \\
EIA license from NEMA & 17.3 \\
Approval by the Public Health & 10.7 \\
Department & \\
Approval by NCA & 22.7 \\
Site plan & 13.3 \\
Approved structural drawings & 6.7 \\
Contract with client & 5.3 \\
Client's permission & 13.3 \\
\hline
\end{tabular}

Results indicate that while most contractors (22.7\%) were only keen to comply with NCA's approval, $17.3 \%$ prioritized obtaining EIA. Notably, $13.3 \%$ revealed that all they required was the client's permission to begin construction. At the same time, only $10.7 \%$ reported requiring approvals from PPD and PHD, respectively. This may suggest that NCA emerges as more stringent in the enforcement of construction quality assurance standards. It is also apparent that contractors place less emphasis on the building plans approved by PPD, which contains enforceable planning standards. This potentially attracts nonconformity with such standards (for example, floor area ratio), therefore contributing to unregulated land-use change. Drawing from the preceding insight, the study sought to find out which planning standards guided contractors. Results suggested that a majority (46\%) cited building height regulation, 2\% British Standards, 4\% European Standards, and Water Resources Management Authority regulations, respectively. However, of great concern was that $44 \%$ reported not to be guided by any planning standard. The problem is compounded by the fact that $22 \%$ of the respondents were not aware of the existence of Kisii Town Physical Development Plan, which is used as a tool for undertaking development control in the study area.

6.2.3 Supervision of building developments during the construction process

Section 16 (1) of the Building Code (1968) requires a person who intends to develop a building to give the planning authority a "Notice of Inspection" card indicating the date and time when the development will begin. It is, therefore, the contractor's responsibility to ensure that the notice is issued to the planning authority. The study, as a result, sought to establish from building contractors, which office supervised their projects and frequency of supervision, an aspect considered necessary since supervision enhances monitoring, conformity, and enforcement. It emerged that only $20 \%$ of projects were supervised during all phases. This potentially creates a gap that encourages developers not to comply with recommended building regulations. Concerning projects which had been supervised, the study, as indicated in Figure 1, examined who supervised them.

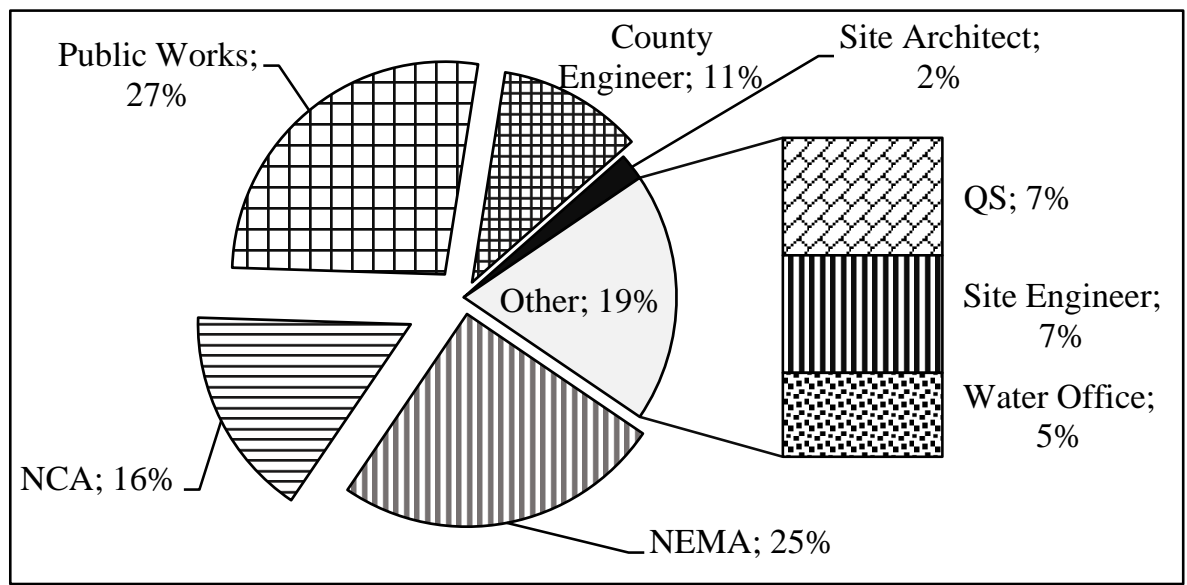

Figure 1: Responsibility for the inspection of building developments

It can be seen that the Public Works Office accounted for $27 \%$ of inspections, followed by NEMA at $25 \%$ to ensure implementation of Environmental Management Plans. NCA accounted for $16 \%$, while Quantity Surveyor (QS) $7 \%$. The frequency of supervision varied at a minimum of one and a maximum of four times. Overall mean was four. What these results denote was that although PPD and PHD approved building developments, they never inspected the same to ascertain compliance. This also creates a missing link that presents developers with an 
opportunity of disregarding the sanctioned planning standards; consequently, a key driver of unplanned landuse change. All these problems occasioned mostly because contractors infrequently invited concerned departments to inspect buildings under construction.

\subsection{Factors induced by NCA: an exploratory and confirmatory factor approach}

After observing that most contractors were not versed with planning standards and laws in addition to the development control process, it was conjectured that the limitation was induced by institutional limitations of the regulator - NCA. This was informed by Section 5 (2) g and k of the NCA Act (2012), which grants the Authority powers to ensure quality assurance in the construction industry, accredit and register contractors, in addition to regulating their professional undertakings. Principal Component Analysis (PCA) was, therefore, used to determine which underlying factors (components) explained why the NCA was not adequately regulating the building construction industry in Kisii Town. PCA is a multivariate method that analyses a data table in which observations are described by several inter-correlated quantitative dependent variables (Abdi and Williams, 2010). Its objective is to summarize data to enable patterns and their associations to be easily comprehended and interpreted. It aims at summarizing data to allow patterns and relationships to be effortlessly deduced and understood. It is usually applied in rearranging variables into a limited set of groups constructed on common variance and assists to segregate concepts and constructs (Yong and Pearce, 2013). Examination of the appropriateness of Factor Analysis was attained using the Kaiser-Meyer Olkin (KMO) and Bartlett's Test, which is commonly applied in research. Reported Chi-square approximation was 345.249 with 91 degrees of freedom, which was significant, $\mathrm{p}=.000$. The KMO of 0.727 was also larger (higher than 0.50 , as recommended by Kaiser, 1974) (Table 2). This gave credibility to PCA as a suitable technique for further Factor Analysis.

Table 2: KMO and Bartlett's test

Kaiser-Meyer-Olkin Measure of Sampling $\quad .727$

Adequacy

\begin{tabular}{lll}
\hline \multirow{2}{*}{ Bartlett's Test } & Approx. Chi-Square & 345.249 \\
of Sphericity: & df & 91 \\
& Sig. & .000 \\
\hline
\end{tabular}

Data collected from sampled building development contractors were subjected to a Principal Axis Factor (PAF) with an orthogonal Varimax rotation of the 15 Likert scale questions. Computation of the variance followed this accounting for the initial solution as well as the rotated components extracted (Table 3). The Initial Eigenvalues are captured in the first part of Table 3. While the total column highlights the amounts of variance in the original study variables accounted for by each component, the percentage of the variance column, reports the ratio, depicted as a percentage of the variance expounded by each component when compared to the aggregate variation within the variables. Additionally, the cumulative percentage column provides the percentage of variance accounted for by the first identified components. For example, the cumulative percentage for the third component is the sum of the percentage of actual variance for the first and second components. Because only the eigenvalues larger than one were extracted, the first three principal components formed the extracted solution, which explains nearly $63.78 \%$ of the variability in the original 14 variables (Table 3 ).

Table 3: Total variance explained by PCA

\begin{tabular}{ccccccc}
\hline & \multicolumn{3}{c}{ Initial Eigenvalues } & \multicolumn{2}{c}{ Extraction Sums of Squared Loadings } \\
\cline { 2 - 6 } Component & Total & \% of Variance & Cumulative \% & Total & \% of Variance & Cumulative \% \\
\hline 1 & 5.99 & 42.80 & 42.80 & 5.99 & 42.80 & 42.80 \\
2 & 1.52 & 10.90 & 53.71 & 1.52 & 10.90 & 53.71 \\
3 & 1.41 & 10.07 & 63.78 & 1.41 & & \\
4 & 1.00 & 7.20 & 70.98 & & \\
5 & .86 & 6.20 & 77.19 & & & \\
6 & .73 & 5.27 & 82.46 & & & \\
7 & .56 & 4.03 & 86.49 & & & \\
8 & .50 & 3.60 & 90.10 & & \\
9 & .37 & 2.67 & 92.77 & & \\
10 & .34 & 2.46 & 95.24 & & \\
11 & .25 & 1.78 & 97.02 & & & \\
12 & .21 & 1.52 & 98.55 & & & \\
13 & .12 & .87 & 99.43 & & & \\
14 & .07 & .56 & 100.00 & & & \\
\end{tabular}

Extraction Method: Principal Component Analysis

In addition to the total variance explained by the PCA (Table 3), outcomes relating to orthogonal rotation of the solution are further presented where Rotated Component

The matrix shows component loadings for each variable or correlation between a variable and a component extracted from the data (Table 4).
Four variables (TMPR, QUAL, COLA, and TRAC) strongly loaded into Component 1 . When they were jointly considered, they seemed to address multi-sectoral coordination. The component was as a result labelled, "Extent of multi-sectoral coordination" because underlying issues could be best explained using a multisectoral coordination approach. Three variables (CMON, 
TRAP, and ENFO) that loaded to Component 2 appeared to be addressing, "Extent of surveillance" since the three identified variables may only become effective if adequate surveillance is guaranteed. Three more variables (ADVI, TRAI, and SUSP) that strongly loaded into Component 3 jointly addressed sensitization. Because identified issues could be adequately addressed through enhanced sensitization. The component was thus labelled, "Extent of sensitization". The identified three principal components (factors elucidating why NCA was not successfully regulating the building construction industry) were further used as latent variables in Structured Equation Modelling (SEM) to test the significance of each component (latent variable) against the corresponding measured variables that loaded on them. This demonstrates the relationship between Confirmatory Factor Analysis (CFA) and Exploratory Factor Analysis (EFA) (Figure 2).

Table 4: Rotated component matrix

\begin{tabular}{lcc}
\hline Variable & \multicolumn{2}{c}{ Principal Components } \\
\cline { 2 - 3 } & \multicolumn{2}{c}{2} \\
\hline Timely registration of construction projects (TMPR) & .777 & \\
Promote quality assurance (QUAL) & .746 & \\
Collaborating with other institutions (COLA) & .732 & \\
Transparency in contractor registration (TRAC) & .692 & \\
The capacity to monitor construction projects (CMON) & & .812 \\
Transparency in project registration (TRAP) & .699 \\
Enforcement of regulations on construction (ENFO) & .680 \\
Advisory services to developers/contractors (ADVI) & & .824 \\
Training construction workers (TRAI) & & .801 \\
Suspension of non-complying contractors (SUSP) & & .719 \\
\hline
\end{tabular}

Rotation Method: Varimax with Kaiser Normalization

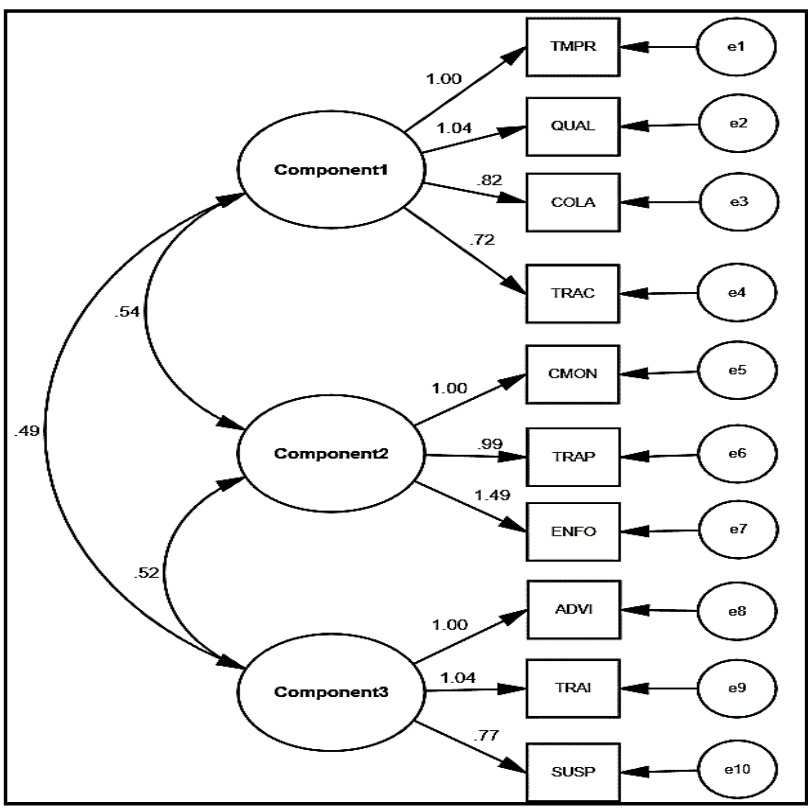

Figure 2 Structural model of the three principal components

The model shows the relationship between the three principal components (latent variables) and their respective measured variables, as well as the correlation between the principal components (Figure 4). SEM represents a statistical method that is used in developing and testing of causal models. It fundamentally represents a mixture of a method that incorporates both facets of CFA, path analysis and multiple regression analysis, and is extensively used by researchers in examining the operational association between measured variables and resultant latent concepts (Loehlin, 2004).

This technique was adopted because it has the advantage of approximating the interconnected and numerous dependency within a single line of inquiry. Among the advantages of SEM is its capability in modelling constructs as relevant latent variables. A latent variable is that variable which cannot be directly measured but customarily inferred by the covariances amongst two or more variables that are measured. According to Loehlin (2004) and Jensen and Janes (2012), principal components act as the latent variables of a PCA model. Measured variables are variables that can be directly measured. They consist of data that has been collected by directly mapping into the constructs of interest.

As a norm, SEM usually begins with a given hypothesis which is signified as a model, followed by the execution of the key paradigms which are being examined with an instrument of measurement and after that, the model testing. In the current study, the hypothesis derived was that the three principal components (latent variables) that occasioned did not influence measured variables that loaded into each of them (Figure 2 and Table 5).

As regards the first latent variable/principal component (multi-sectoral coordination), when it goes up by 1.000, TMPR, QUAL, COLA, and TRAC respectively go up by $1.000,1.038,0.816$ and 0.716 , thus significantly predicting its four measured variables, $\mathrm{p}=.000, \mathrm{CR}$ > 1.96. This suggests that if multi-sectoral coordination that is currently inadequate improves, it will contribute to an equal improvement in TMPR, QUAL, COLA, and TRAC. The converse will follow if multi-sectoral co-ordination declines. Concerning the second principal component (extent of surveillance), it was further demonstrated that when it goes up by one unit, CMON, TRAP, and ENFO would respectively go up by 1.000, 0.985 and 1.493 .

As the case of multi-sectoral coordination, extent of surveillance also predicted its three variables $(\mathrm{p}=.000$, $\mathrm{CR}>$ 1.96). This implies that an increase in the surveillance of building developments in Kisii Town would significantly promote the enforcement of applicable standards. Equally, in the absence of adequate 
surveillance, unregulated building development would ensue at the detriment of effective development control. Lastly, the third component (extent of sensitization) also significantly predicted its variables, $\mathrm{p}=.000, \mathrm{CR}>1.96$ ). Hence, if sensitization increases by one unit, ADVI, TRAI, and SUSP will respectively increase by 1.000 , 1.039 , and .773 . This connotes that the improvement in the sensitization of building contractors and their sensitization through training would lead to capacity building. Therefore, providing an opportunity for reprimanding noncomplying contractors since most of them would be aware of the applicable standards within the construction industry. The model in the end passed the test for goodness of fit, where Chi-square, $\chi 2=55.594, \mathrm{df}$ $=32, \mathrm{p}=.006$.

Table 5: Regression weights and significance test for SEM

\begin{tabular}{llllll}
\hline $\begin{array}{l}\text { Measured } \\
\text { Variable }\end{array}$ & $\begin{array}{l}\text { Path } \\
\text { Direction }\end{array}$ & $\begin{array}{l}\text { Latent Variable/ } \\
\text { Component }\end{array}$ & $\begin{array}{l}\text { Estimated } \\
\text { (Regression weights) }\end{array}$ & $\begin{array}{l}\text { Critical Ratio } \\
\text { (CR) }\end{array}$ & P \\
\hline TMPR & $<---$ & 1 & 1.000 & 4.858 & .000 \\
QUAL & $<---$ & 1 & 1.038 & 3.864 & .000 \\
COLA & $<---$ & 1 & .816 & 3.628 & .000 \\
TRAC & ---- & 1 & .716 & .000 \\
CMON & $<---$ & 2 & 1.000 & 3.267 & .000 \\
TRAP & $<---$ & 2 & .985 & 3.741 & .000 \\
ENFO & ---- & 2 & 1.493 & .000 \\
ADVI & ---- & 3 & 1.000 & 5.398 & .000 \\
TRAI & $<---$ & 3 & 1.039 & .773 & .000 \\
SUSP & $<---$ & 3 & & .339 \\
\hline
\end{tabular}

Given the observed relationships between each component and their respective measured variables, the model further tested the correlation between the three components. Results indicated that the correlation between multi-sectoral coordination and extent of sensitization was positive and significant, $\mathrm{r}=.491, \mathrm{p}=$ .024 , the same applied to the relationship between the degree of surveillance and extent of sensitization, $r=.521$, $\mathrm{p}=$. 014 and so was the case of multi-sectoral coordination and extent of surveillance, $\mathrm{r}=.543, \mathrm{p}=.012$. These relationships infer that an increase in multi-sectoral coordination would result in an improved sensitization of building contractors and developers; likewise, improved surveillance will enhance sensitization of contractors and developers. At the same time, enhanced multi-sectoral coordination leads to analogous improvement in surveillance. These are construed as essential tenets in containing the unplanned land-use change.

The findings of this study align with that of Gacheru (2015), which established that factors limiting regulation of contractors in Kenya included inadequate human resource capacity, unsatisfactory enforcement of regulations and limited sensitization. The findings also agree with that of Ofori-Kuragu et al. (2016), who established that the fragmentation of stakeholders hinders regulation of the Ghanaian construction industry. However, unlike Gacheru (2015) and Ofori-Kuragu et al. (2016), the current study, through statistical quantifications determined the extent of association between key variables that impacts on the successful regulation of the building construction industry, therefore further contributing to the existing body of literature on the built environment.

\section{Conclusion and Recommendations}

\subsection{Conclusion}

Sustainable urban development may not be fully attained in Kenya if a lapse frequently occurs in the regulation of its vibrant construction industry. This study demonstrates that the barriers to the effective regulation of the building construction industry in the study area may be itemised as those induced by building contractors and those induced by NCA as their regulator. In this case, factors influenced by NCA comprised the low extent of multi-sectoral coordination, limited surveillance and inadequate sensitization of contractors and developers. Conversely, factors induced by contractors included inconsistencies in the application of relevant laws, failure to get prerequisite approvals before commencing construction, disregard of planning standards and failure to involve relevant government departments in the inspection of building development during constructions. As regards the implication of research findings, the study has validated the theorised interplay between the critical factors that may directly influence the regulation of building construction industry. This, in turn, can serve a learning outcome in addition to providing insight into the quest for achieving sustainable regulation of the building construction industry for both developing and developed countries.

Although this paper examined key barriers to the effective regulation of the building construction industry, its limitation was that data collection and subsequent analysis focused on residential building developments. However, this gap provides an opportunity for further research with a possible interrogation on how concerned planning authorities also regulate the construction of other categories of building developments (such as commercial, educational, public purpose, and industrial), a tactic for promoting sustainable urban development, and recently, attaining the objectives of the emerging concept of a 'smart city.

\subsection{Recommendations}

Contractors should ensure that before the commencement of construction, their clients have obtained all applicable statutory approvals from respective approving authorities. 
They should also ensure that the projects they are undertaking are supervised at all phases by relevant authorities.

There is a need to consistently undertake enforcement and surveillance audits that would promote compliance with approved building regulations by developers in Kisii Town. To attain this inquest, the function of building development control should be decentralized to the location levels. This will make NCA, and the County Government of Kisii have a direct presence at the neighbourhood levels leading to increased incidences in monitoring and enforcement. To actualise this strategy, NCA and the County Government should undertake regular public education campaigns targeting developers on the importance rather than punitive nature of building development control. Additionally, the two lead agencies should jointly prepare comprehensive legislation on building development control through a participatory approach by engaging key stakeholders. This will make the "regulated" to own and directly participate in the regulation process.

NCA should organize regular training workshops for building contractors to deepen their understanding of the benefits of building development regulations, including applicable legislation in the built environment.

All County Government departments involved in the inspection of development projects should have joint

\section{References}

Abdi, H., and Williams, L.J. 2010. Principal component analysis. WIREs Computational Statistics, 2, 433-439.

Adebowale, P.A., Gambo M.D, Ankeli, I.A., and Dabara, D.I. 2016. Building collapse in Nigeria: Issues and challenges. Conference of the International Journal of Arts \& Sciences, 09(01), 99-108.

Amiri, A.F. and Bausman, D.C. 2018. The internationalization of construction industry - A global perspective. International Journal of Engineering Science Invention (IJESI), 7 (8), 59-68.

Anyanwu, C.I. 2013. The role of building construction project team members in building project delivery. Journal of Business and Management, 14 (1), 30-34.

Callistus, T. Anzagira L.F. Kissi, E. Balaara S. and Anzagira, C.E. 2014. Factors affecting quality performance of construction firms in Ghana: Evidence from small-scale contractors. Civil and environmental research, 6 (5), 18-23.

Christensen, J. G. 2010. Public interest regulation reconsidered: From capture to credible commitment", paper presented at Regulation at the Age of Crisis, ECPR Regulatory Governance Standing Group, 3rd Biennial Conference, University College, Dublin, June 17-19, 2010. [Online]. https:// www. semanticscholar .org/paper/Public-interest-regulation-reconsidered-Fromto-Christensen /2426c00f 43b54cfc12fb0f 61301c8 96d5eb2636e (17 February 2019).

Competition Authority of Kenya. 2017. The construction industry analysis of the state of competition. [Online].https://www.cak.go.ke/Images/new/june/ Construction _Industry_Study_Report.pdf (14 March 2019). inspection schedules to ensure uniformity in the enforcement of compliance.

A Coordinating Committee should be established to harmonize various agencies (such as NEMA, NCA and Public Health) that undertake building development control, thus eliminating duplication in enforcement efforts.

As a long term strategy, the NCA should be wound up and its functions transferred to the county governments because it duplicates their development control function, an exclusive function of the county governments in Kenya. This is as provided for under Part XI of the County Governments Act (2012) as further read with Section 29 of the Physical Planning Act of 1996. The county governments in Kenya, through appropriate legislation, should, therefore, be further empowered to undertake the function of registration and accreditation of building contractors operating within their respective spatial jurisdictions.

The penalties of not complying with building development control requirements under the Physical Planning Act of 1996 should be reviewed upwards to deter developers from noncompliance. Further, the NCA Act of 2011 should also be examined to give NCA the powers to directly prosecute non-complying contractors and developers.

Cronbach, L. J. 1951. Coefficient alpha and the internal structure of tests. Psychometrika, 16, 297-334

Gacheru, E.N. and Diang'a S.O. 2015. Regulating building contractors in Kenya and challenges of enforcing the National Construction Authority Mandate. International Journal of Soft Computing and Engineering (IJSCE), 5 (1), 127-133.

Gacheru, E.N. 2015. An investigation into the national construction authority's challenges in regulating building contractors: The Case of Mombasa County. [Online]. http://ir.jkuat.ac.ke/ handle/ 1234567 89/1867 (12 March 2019).

Gichana, A. and Nyagesiba, B. 2016. Six killed, 43 injured after building collapses in Kisii town. The Star. [Online] https://www.the-star.co.ke/news/2016-11-10six-killed-43-injured-after-building-collapses-in-kisiitown/ (24 April 2019).

Goforth, N. 2003. Using and interpreting Cronbach's Alpha. [Online] http://data.library.virginia.edu/usingand-interpreting-cronbachs-alpha/ (19 April 2019).

Hedidor, D.I. and Bondinuba F. K. 2017. Exploring concrete materials batching behaviour of artisans in Ghana's informal construction sector. Journal of Civil Engineering and Construction Technology, 8(5), 35-52.

Jensen, K. J. and Janes, K. A. 2012. Modelling the latent dimensions of multivariate signalling datasets, Physical Biology, 9 (4), 1-2.

Kenya National Bureaus of Statistics. 2018. Economic Survey, Government Printer, Nairobi.

Kaiser, H. F. 1974. An index of factorial simplicity”, Psychometrika, 39, 31-36. [Online] https://link. Springer. com/article/ 10.1007/BF02291575 (26 April 2019).

Khan, A.Z. 2008. Role of Construction Sector in Economic Growth: Empirical Evidence from Pakistan Economy. A paper presented at the First International 
Conference on Construction in Developing Countries (ICCIDC-I) August 4-5, 2008, Karachi, Pakistan. [Online]. https://www.researchgate.net/ publication/ 283007781_Role_of_Construction_Sector_in_Economic _Growth_Empirical_Evidence_from_Pakistan_Economy /references (22 April 2019).

Kothari, G.R. 2004. Research methodology, methods and techniques (second revised edition). New Age International (P) Limited Publishers: New Delhi.

Krejcie, R.V., and Morgan, D.W. 1970. Determining sample size for research activities. Educational and Psychological Measurement, 30, 607-610.

Kumar, A., and Pushplata. 2015. Building regulations for hill towns of India. HBRC Journal, 11 (2), 275-282.

Litwin, M. S. 2002. How to assess and interpret survey psychometrics, 2nd edition, Sage Publications, In, Thousand Oaks, CA.

Loehlin, J. C. 2004. Latent variable models: An introduction to factor, path, and structural equation analysis (4th Ed.), Erlbaum.

Mugenda, A. and Mugenda, O. 2003. Research methods: Quantitative and qualitative approaches. Acts Press: Nairobi.

Ngetich, J.K, Opata, G.P. and Mulongo, L.S.2014. A Study on the Effectiveness of Urban Development Control Instruments and Practices in Eldoret Municipality, Kenya. Journal of Emerging Trends in Engineering and Applied Sciences, 5(2): 83-91

Nhabinde, V. Marrengula, C.P. and Ubisse, A. 2012. The Challenges and the way forward for the construction industry in Mozambique. [Online] https://www. theigc.org/wp-content/ uploads/ 2014/09 /Nhabine-Et-Al2012-Working-Paper.pdf. (26 April 2019).

Ofori-Kuragu, J.K., Owusu-Manu, D.G., and Ayarkwa, J. 2016. The Case for a Construction Industry Council in Ghana. Journal of Construction in Developing Countries, 21(2), 131-149

Oladinrin, T. O. Ogunsemi, D. R. and Aje, I. O. 2012. Role of the construction sector in economic growth: Empirical evidence from Nigeria, FUTY Journal of the Environment, 7 (1), 81-89.
Omollo, W.O., Hayombe, P.O., and Owino, F.O. 2018. Compliance with physical planning standards by residential developments in Kisii Town, Kenya, Architecture Research, 8 (2), 62-73.

The Republic of Kenya .1968. Building Code, Government Printer, Nairobi.

The Republic of Kenya. 1996. Physical Planning Act (Cap. 286), Government Printer, Nairobi.

The Republic of Kenya .1999. Environmental Management and Co-ordination Act (Cap. 387), Government Printer, Nairobi.

The Republic of Kenya .2008. Vision 2030: The Popular Version. [Online] https: //vision 2030.go.ke/publication/kenya-vision-2030-popularversion/ (24 April 2019).

The Republic of Kenya. 2011. National Construction Authority Act, Government Printer, Nairobi.

The Republic of Kenya .2012. County Governments Act. Government Printer, Nairobi.

The Republic of Kenya .2014. National Construction Authority Regulations: Government Printer, Nairobi.

Twum-Darko, M. and Mazibuko, P.N.2015. Compliance and enforcement challenges: A case of the national building regulations' processes in South Africa. Journal of Governance and Regulation, 4 (1), 655-660

Wibowo, A.2009. The contribution of the construction industry to the economy of Indonesia: A systemic approach. [Online] http://eprints.Undip .ac.id/387/ (26 April 2019)

Windapo, A., and Cattell, K. 2010. A study of building contractors' compliance with national building regulations in Cape Town. [Online] https:// www.researchgate.net/ publication/286821693 A study_of_building_contractors\%27_compliance_with_na tional_building_regulations_in_Cape_Town. (30 May 2019).

Yong, A., G., and Pearce, S. 2013. A beginners 'guide to factor analysis: Focusing on exploratory factor analysis. Tutorials in Quantitative Methods for Psychology, 9 (2), 79-94. 